\title{
RASIO LIKUIDITAS, RASIO SOLVABILITAS, RASIO RENTABILITAS KOPERASI JASA KEUANGAN SYARIAH DI JAWA TENGAH
}

\author{
Rahmat Nuryanto'), Muhammad Tho'in ${ }^{2)}$, Herlina Kusuma Wardani ${ }^{3)}$ \\ Sekolah Tinggi Ilmu Ekonomi AAS Surakarta \\ Email:rahmat.nuryanto@gmail.com \\ Email:thoinsyakira@yahoo.com \\ Email:herlinaorli2@gmail.com
}

\begin{abstract}
This study aims to determine the ratio of liquidity, solvency and profitability which is the financial performance of KJKS Mass Group Sragen. The research method has been done in the form of quantitative descriptive percentage. The research data is obtained from financial report of KJKS Mass Group Sragen. The results showed that: (1) Based on the liquidity ratio shows the amount of good or liquid in the analysis of Current Ratio is $122.01 \%$ in 2012 and $153.11 \%$ in 2013, while the Cash Ratio analysis shows good results because it is still far below predefined standards; (2) Given the solvency ratio shows good or unbreakable results in meeting its obligations and short term; (3) Meanwhile, based on profitability or profitability ratios indicate that KJKS Mass Group is not rentable in generating maximum net profit.
\end{abstract}

Keywords: liquidity ratio, solvency ratio, rentability ratio, sharia financial services cooperative

\section{PENDAHULUAN}

Perusahaan atau lembaga sebagai bentuk organisasi pada umumnya memiliki tujuan tertentu yang diharapkan keberhasilannya, khususnya kepada para anggotanya. Keberhasilan dalam mencapai tujuan perusahaan merupakan bagian penting sebagai prestasi dari manajemen. Penilaian sebuah kinerja atau prestasi suatu perusahaan diukur karena dapat dipakai sebagai dasar pengambilan kebijakan dan atau keputusan baik terhadap pihak eksternal maupun internal perusahaan. Kinerja keuangan perusahaan merupakan suatu gambaran tentang kondisi dan posisi keuangan suatu lembaga atau perusahaan yang dapat dianalisis menggunakan alat-alat analisis keuangan, sehingga dapat diketahui mengenai baik dan buruknya keadaan dari keuangan sebuah perusahaan yang dapat mencerminkan prestasi kerja dalam periode tertentu. Hal Jurnal Akuntansi Dan Pajak, Vol 15, No. 01, Juli 2014 ini sangat penting supaya sumber daya yang dimiliki digunakan maksimal dalam rangka menghadapi perubahan lingkungan.

Penilaian kinerja keuangan merupakan salah satu metode yang dapat dilaksanakan oleh pihak pengelola agar dapat memenuhi kewajibannya terhadap para penyandang dana atau investor dan juga untuk menggapai tujuan perusahaan yang sudah ditetapkan sebelumnya. Cara untuk mengetahui baik buruknya kinerja keuangan di suatu lembaga atau perusahaan dapat dilakukan berbagai cara di antaranya dengan menganilisis hubungan dari berbagai pos dalam suatu laporan keuangan perusahaan tersebut.

Beberapa alat analisis prestasi/kinerja keuangan sebuah perusahaan yang digunakan secara umum meliputi rasio likuiditas, rasio solvabilitas serta rasio rentabilitas. Dalam penilain, Rasio likuiditas untuk menilai sejauh mana kemampuan perusahaan dalam 
memenuhi semua kewajiban-kewajiban jangka pendek dengan menggunakan jaminan harta lancar yang dimilikinya. Kemudian rasio solvabilitas, untuk menunjukkan seberapa kemampuan dari perusahaan tersebut bisa memenuhi semua kewajibannya dengan jaminan harta yang dimiliki perusahaan tersebut. Sedangkan rasio profitabilitas atau rentabilitas, untuk mengetahui kemampuan perusahaan dalam menghasilkan laba atau keuntungan selama kurun waktu tertentu serta memberikan suatu gambaran tentang tingkat efektifitas manajemen dalam melaksanakan kegiatan operasinya.

Sama halnya dengan perusahaan pada umumnya, koperasi jasa keuangan syariah juga memerlukan suatu alat analisis untuk mengetahui tingkat kinerja keuangan agar manajemen dari pihak koperasi dapat melaksanakan tugas dan kewajibannya dengan baik sesuai dengan tujuan yang diharapkan. Dengan mengetahui rasio-rasio tersebut, akan dapat diketahui keadaan yang sesungguhnya sehingga dapat diukur tingkat kinerja keuangan dalam perusahaan atau koperasi jasa keuangan syariah tersebut.

\section{TUJUAN PENELITIAN}

Penelitian ini bertujuan untuk mengetahui tingkat kinerja keuangan pada KJKS Mass Group ditinjau dari rasio likuiditas, rasio solvabilitas serta rasio rentabilitas; dan untuk mengetahui keadaan dan posisi keuangan yang dimilikinya.

\section{KAJIAN PUSTAKA \\ Kinerja}

Kinerja merupakan hasil kerja dinilai secara kualitas dan kuantitas yang dapat dicapai pegawai dalam menjalankan tugas yang diemban sesuai dengan tanggung jawab yang diberikan kepadanya (Mangkunegara,
2000: 67). Pendapat tersebut didukung Hasibuan (2001:34). Sulistiyani menambahkan, hasil kerja yang dinilai melalui kombinasi dari kemampuan, usaha, serta kesempatan atau peluang merupakan kinerja.

Kinerja merupakan suatu kondisi yang harus diketahui serta dikonfirmasikan untuk para pihak yang bersangkutan, untuk melihat tingkat pencapaian hasil suatu instansi dihubungkan dengan visi serta mengetahui dampak positif dan negatif dari suatu kebijakan-kebijakan operasionalnya. Individu yang memiliki kinerja yang tinggi memiliki beberapa karakteristik khusus. Diantara karakteristik tersebut: (a) individu yang selalu berorientasi prestasi, (b) memiliki percaya diri, (c) berperngendalian diri, (d) kompetensi (Mink, 1993 : 76).

Tujuan penilaian kinerja perusahaan menurut Munawir (2000:31). Pertama, untuk menilai sejauh mana kemampuan perusahaan dalam memenuhi semua kewajiban-kewajiban jangka pendek dengan menggunakan jaminan harta lancar yang dimilikinya (tingkat likuiditas). Kedua, untuk mengetahui tingkat solvabilitas, yaitu kemampuan untuk menunjukkan seberapa kemampuan dari perusahaan tersebut bisa memenuhi semua kewajibannya dengan jaminan harta yang dimiliki perusahaan tersebut dilikuidasi baik kewajiban keuangan jangka pendek maupun jangka panjang. Ketiga, untuk mengetahui tingkat rentabilitas atau profitabilitas, yaitu menunjukkan untuk mengetahui kemampuan perusahaan dalam menghasilkan laba atau keuntungan selama kurun waktu tertentu serta memberikan suatu gambaran tentang tingkat efektifitas manajemen dalam melaksanakan kegiatan operasinya. Serta tujuan akhirnya untuk mengetahui tingkat kemampuan usaha perusahaan dalam melakukan usahanya dengan stabil, yang diukur dengan mengukur kemampuan yang dimiliki perusahaan dalam 
membayar beban atas bunga dari berbagai pinjaman termasuk membayar kembali pokok hutangnya tepat pada waktunya dan mampu melakukan pembayaran deviden kepada pemegang saham dengan lancar tanpa mengalami hambatan keuangan.

Dalam penilaian kinerja tentunya memiliki berbagai manfaat yang dapat membantu perusahaan. Manfaat dari penilaian kinerja perusahaan antara lain:

1. Untuk mengukur prestasi yang dicapai oleh suatu organisasi dalam suatu periode tertentu yang dapat mencerminkan berbagai tingkat keberhasilan dalam melaksanakan aktifitasnya.

2. Untuk melihat kinerja organisasi secara keseluruhan, pengukuran dalam prestasi atau kinerja dalam menilai suatu kontribusi per bagian dalam pencapaian tujuan perusahaan secara keseluruhan.

3. Dapat digunakan sebagai dasar penentuan strategi perusahaan untuk masa yang akan datang.

4. Memberi berbagai petunjuk untuk pembuatan berbagai keputusan dalam kegiatan yang dilakukan perusahaan pada umumnya, dan divisi atau bagian organisasi pada khususnya.

5. Untuk fondasi di dalam menentukanan berbagai kebijakan penanaman investasi agar dapat meningkatkan efisiensi dan produktivitas perusahaan.

\section{Analisis Laporan Keuangan}

Analisis merupakan penguraian suatu persoalan atau permasalahan serta menjelaskan suatu hubungan antara bagianbagian untuk disimpulkan secara keseluruhan melalui sebuah pengertian. Sedangkan laporan keuangan adalah suatu ringkasan yang diperoleh dari pencatatan yang diproses, serta sebuah ringkasan dilalui dari transaksi keuangan yang terjadi selama satu tahun buku yang bersangkutan (Baridwan, 2004:17). Sedangkan definisi yang dikeluarkan oleh Ikatan Akuntan Indonesia (IAI) laporan keuangan merupakan bagian dari proses pelaporan keuangan. Dikatakan lengkap jika memiliki setidak-tidaknya berupa: Neraca, laba rugi, laporan keuangan yang dapat disajikan dalam bentuk. Sebuah laporan dibuat perusahaan oleh pihak manajemen merupakan alat untuk mempertanggung jawabkan kepada pemilik atau pemegang saham.

Dalam buku Analisa Laporan Keuangan (Nainggolan, 2004), Laporan keuangan adalah bersifat historis serta menyeluruh dan sebagai suatu progress report laporan keuangan terdiri dari berbagai data hasil dari kombinasi antara fakta yang telah dicatat (Recorded Fact), prinsip-prinsip serta sebuah kebiasaan), dan pendapat pribadi (Personal Judgement) dari masing-masing personel atau individu.

Dengan memperhatikan berbagai sifat laporan keuangan di atas, maka dapat ditarik kesimpulan bahwa laporan keuangan mempunyai keterbatasan-keterbatasan diantaranya:

Laporan keuangan yang dibuat secara periodik pada dasarnya merupakan laporan yang dibuat periode yang sifatnya sementara dan bukan merupakan laporan yang bersifat final. Oleh karena itu, hal atau jumlah yang dilaporkan dalam laporan keuangan tidak menunjukkan nilai likuid dimana intern report ini terdapat pendapat-pendapat pribadi yang telah dilakukan oleh manajemen atau akuntan. Laporan finansial dibuat berdasarkan anggapan bahwa perusahaan akan berjalan historis atau harga perolehannya, dan pengurangan tersebut dilakukan untuk aktiva tetapnya tersebut sebesar akumulasi depresinya. Karena itu angka yang tercantum di dalam laporan tersebut hanya nilai buku 
yang bisa jadi belum tentu sama dengan harga pasar sekarang maupun nilai gantinya. Laporan keuangan disusun berdasarkan hasil pencatatan transaksi keuangan atau nilai rupiah dari berbagai waktu atau tanggal yang lalu, dimana daya beli uang tersebut semakin menurun, dibandingkan dengan tahun-tahun sebelumnya, sehingga kenaikan volume penjualan yang dinyatakan dalam rupiah belum tentu menunjukkan unit yang dijual semakin besar. Mungkin kenaikan itu disebabkan naiknya harga jual barang tersebut yang mungkin diikuti kenaikan tingkat hargaharga. Jadi suatu analisis dengan membandingkan data beberapa tahun tanpa membuat penyesuaian terhadap perubahan tingkat harga akan diperoleh kesimpulan yang keliru. Laporan keuangan tidak dapat mencerminkan berbagai faktor yang dapat mempengaruhi posisi atau keadaan keuangan perusahaan karena faktor-faktor tersebut tidak dinyatakan dengan satuan uang (Nainggolan, 2004).

\section{Analisis Rasio}

Menurut Munawir (2002:33), Analisis Rasio merupakan suatu metode analisa untuk mengetahui hubungan dari pospos tertentu. Dengan menggunakan laporan tentang perubahan data-data untuk diperbandingkan yang terjadi dalam jumlah rupiah, prosentase serta trendnya, ratio individu akan membantu dalam menganalisa dan menginterpretasikan tingkat posisi perusahaan khususnya di bidang keuangan.

Rasio perusahaan bidang keuangan menggambarkan tingkat hubungan atau perimbangan (mathematical relationship) antara kuantitas tertentu dengan kuantitas lainnya, serta dengan menggunakan alat analisa berupa ratio ini akan dapat menjelaskan serta memberikan suatu gambaran analisator mengenai baik buruknya keadaan atau posisi keuangan suatu perusahaan terutama jika ratio itu diperbandingkan angka ratio pembanding yang digunakan sebagai standard.

\section{Ruang Lingkup KJKS}

Koperasi Jasa Keuangan Syariah adalah sebuah lembaga keuangan yang menerapkan prinsip syariah yaitu menggunakan sistem bagi hasil dalam operasionalnya. KJKS atau BMT juga merupakan lembaga keuangan atau bisnis yang serupa dengan koperasi atau lembaga swadaya masyarakat (Muhammad, 2005: 135)

Lembaga keuangan syariah atau lembaga keuangan Islam yang sekarang populer salah satunya adalah koperasi jasa keuangan syariah (KJKS) sudah ada sejak zaman dahulu, yaitu sejak zaman Khulafaur Rasyidin, bahkan konsep awalnya sudah ada sejak zaman Rasulullah SAW (Wardani \& Tho'in, 2013).

Baitul maal wat tamwil Sebagai sebuah lembaga Koperasi Jasa Keuangan Syariah (KJKS) sekaligus sebagai lembaga intermediasi antara penghimpunan dan penyaluran dana dari dan untuk masyarakat (Tho'in, 2011).

Sedangkan BMT menurut PINBUK dalam peraturan dasarnya; "Baitul maal waat tamwil merupakan lembaga ekonomi diperuntukan untuk masyarakat kecil, berupaya mengembangkan investasi dan usaha produktif berdasarkan prinsip Islam atau syariah serta prinsip-prinsip koperasi." Definisi di atas dapat ditarik kesimpulan bahwa BMT adalah suatu lembaga bisnis dengan badan hukum koperasi yang bertujuan ikut berperan serta dalam pengembangan masyarakat kecil dengan mendasarkan pada prinsip syariah. Baitul maal wat tamwil sebagai lembaga keuangan mikro dalam perkembangannya mempunyai beberapa 
persamaan dengan bank syariah, terutama dalam praktik bagi hasil dan rujukan kegiatan operasional syariah mengacu dari fatwa-fatwa DSN MUI.

$$
\text { Menurut Kepmen No. }
$$

91/Kep/M.KUKM/IX/2004, Koperasi Jasa

Keuangan Syariah adalah koperasi yang kegiatan bidang usahanya bergerak di pembiayaan, simpanan maupun investasi sesuai pola bagi hasil (syariah). BMT adalah lembaga keuangan di bidang mikro syariah, dengan tujuan profit oriented dengan Baituttamwilnya, dan social oriented dengan Baitul maalnya.

Menurut Prof. DR. Ir. M. Amin Azis Baitul Maal wat Tamwil atau padanan kata Balai Usaha Mandiri Terpadu merupakan suatu lembaga micro finance dioperasikan dengan prinsip bagi hasil, menumbuh kembangkan bisnis usaha kecil dalam rangka untuk meningangkat tingkat derajat serta martabat, membela kepentingan kaum fakir miskin

\section{METODE PENELITIAN}

Studi deskriptif berupa pengumpulan data-data untuk dilakukan pengujian merupakan jenis dari penelitian yang dilakukan. Sedangkan KJKS Mass Group merupakan tempat dalam melakukan penelitian yang dilakukan.

\section{Metode Pengumpulan Data}

Laporan keuangan KJKS Mass Gruop yang diperoleh oleh peneliti di dalam pengumpulan data, disamping pengumpulan melalui wawancara, observasi maupun studi pustaka.

\section{Metode Analisis Data}

Deskriptif kuantitatif prosentase digunakan menganalisis dari data-data yang diperoleh. Deskriptif adalah tulisan yang Jurnal Akuntansi Dan Pajak, Vol 15, No. 01, Juli 2014 berupa paparan dan atau uraian tentang obyek penelitian. Sedangkan yang dimaksud Kuantitatif ialah data yang mampu diolah atau dapat diukur. Kemudian, prosentase berupa data untuk menyajikan analisis mengenai suatu obyek dengan menggunakan tingkatan persen.

\section{HASIL PENELITIAN}

1. Analisis Rasio likuiditas

Menilai sejauh mana kemampuan KJKS Mass Group dalam memenuhi semua kewajiban-kewajiban jangka pendek dengan menggunakan jaminan harta lancar yang dimilikinya.

a. Current ratio

Dihasilkan rasio sebesar $122,01 \%$ untuk tahun 2012, hal ini menunjukkan setiap Rp.100,00 untuk hutang lancar KJKS Mass Group dijamin sebesar Rp.122,01 dari aktiva lancar yang dimilikinya.

Dihasilkan rasio sebesar $153,11 \%$ untuk tahun 2013, hal ini menunjukkan setiap Rp.100,00 untuk hutang lancar KJKS Mass Group dijamin sebesar Rp.153,11 dari aktiva lancar yang dimilikinya.

b. Cash ratio

Menilai kemampuan yang dimiliki KJKS Mass Group dari sisi kas dibandingkan hutang lancarnya.

Dihasilkan rasio sebesar 14,29\% untuk tahun 2012, hal ini menunjukkan setiap Rp.100,00 untuk hutang lancar KJKS Mass Group dijamin sebesar Rp.14,29 dari kas yang dimiliki dalam memenuhi kewajiban-kewajibannya.

Dihasilkan rasio sebesar $8,81 \%$ untuk tahun 2013, hal ini menunjukkan setiap Rp.100,00 untuk hutang lancar KJKS Mass Group dijamin sebesar Rp.8,81 dari kas yang dimiliki dalam memenuhi kewajiban-kewajibannya. 


\section{Analisis Rasio Solvabilitas}

Menilai kemampuan dalam memenuhi berbagai kewajiban-kewajiban keuangan baik jangka pendek, maupun kewajiban-kewajiban jangka panjangnya. KJKS Mass Group dikatakan solvabel jika KJKS Mass Group memiliki kekayaan cukup dalam membayar hutang-hutang yang dimilikinya. Tetapi jika keadaannya justu sebaliknya maka KJKS Mass Group mengalami insolvabel.

a. Total dept to total asset ratio

Dihasilkan rasio sebesar 91,46\% untuk tahun 2012, hal ini menunjukkan setiap Rp. 91,46 hutang KJKS Mass Group dijamin sebesar Rp.100,00 dari asset.

Dihasilkan rasio sebesar $91,58 \%$ untuk tahun 2013, hal ini menunjukkan setiap Rp. 91,58 hutang KJKS Mass Group dijamin sebesar Rp.100,00 dari asset.

\section{b. Long term dept to equity ratio}

Dihasilkan rasio sebesar $255,13 \%$ untuk tahun 2012, hal ini menunjukkan setiap Rp. 255,13 hutang KJKS Mass Group jangka panjang dijamin sebesar Rp.100,00 dari modal sendiri yang diinvestasikan.

Dihasilkan rasio sebesar $190,57 \%$ untuk tahun 2013, hal ini menunjukkan setiap Rp. 190,57 hutang KJKS Mass Group jangka panjang dijamin sebesar Rp.100,00 dari modal sendiri yang diinvestasikan.

\section{Analisis Rasio Rentabilitas}

Menilai kemampuan KJKS Mass Group untuk memperoleh sisa hasil usaha pada setiap periode. Rentabilitas KJKS Mass Group dapat diukur melalui kesuksesan KJKS Mass Group serta kemampuan dalam menggunakan aktiva yang dimilikinya secara baik.

Jurnal Akuntansi Dan Pajak, Vol 15, No. 01, Juli 2014

\section{a. Return of investment}

Mengukur tingkat kemampuan KJKS Mass Group dengan keseluruhan dana yang diinvestasikan dalam aktiva untuk operasi dalam menghasilkan sisa hasil usaha semaksimal mungkin.

Dihasilkan rasio sebesar $1,81 \%$ untuk tahun 2012, hal ini menunjukkan setiap Rp.1,00 aktiva KJKS Mass Group dapat menghasilkan SHU sebesar Rp.1,81.

Dihasilkan rasio sebesar $1,88 \%$ untuk tahun 2013, hal ini menunjukkan setiap Rp.1,00 aktiva KJKS Mass Group dapat menghasilkan SHU sebesar Rp.1,88.

\section{b. Return on equity}

Menilai sisa hasil usaha yang dibandingkan dengan jumlah modal sendiri. Hal ini menggambarkan kemampuan modal KJKS Mass Group dalam menghasilkan SHU dalam proses aktifitasnya.

Dihasilkan rasio sebesar $25.96 \%$ untuk tahun 2012, hal ini menunjukkan setiap Rp.1,00 modal KJKS Mass Group yang diinvestasikan dapat menghasilkan SHU sebesar Rp.25,96.

Dihasilkan rasio sebesar 27,79\% untuk tahun 2013, hal ini menunjukkan setiap Rp.1,00 modal KJKS Mass Group yang diinvestasikan dapat menghasilkan SHU sebesar Rp.27,79.

\section{PEMBAHASAN}

\section{Rasio Likuiditas}

\section{a. Current Ratio}

KJKS Mass Group dalam 2 tahun yaitu 2012 dan 2013 mempunyai angka rasio lancar $122,01 \%$ dan 153,11 di mana kedua dari angka rasio itu menunjukkan hasil kriteria kurang baik serta kriteria baik. Dari hasil analisis, menunjukkan KJKS Mass Group 
mempunyai aktiva lancar cukup likuid untuk membayar seluruh kewajiban (jangka pendek).

b. Cash Ratio

Rasio ini membandingkan kas KJKS Mass Group dengan semua hutang lancarnya. Analisis Cash Ratio selama tahun 2012 dan 2013 pada KJKS Mass Group hanya menghasilkan tingkat angka rasio $14,29 \%$ dan angka rasio $8,81 \%$. Dalam analisis Cash Ratio juga dihasilkan tingkat angka yang masih jauh dibawah dari standar yang ditetapkan. Hal ini disebabkan, karena pada analisis ini tidak mengikutsertakan akun piutangnya. Sedangkan KJKS Mass Group ini bergerak khususnya dalam bidang penyimpanan maupun pinjaman di mana sebagian besar dari aktivanya yang diperoleh dari perputaran pinjaman KJKS Mass Group yang diberikan kepada anggotanya.

Analisis ini menunjukkan kas yang dimiliki KJKS Mass Group tidak cukup likuid dalam membayar semua hutang lancer yang dimilikinya, sering disebut illikuid. Hal tersebut dapat memperlambat aktifitas KJKS Mass Group, oleh karena itu manajemen KJKS Mass Group untuk senantiasa agar kasnya tetap banyak agar mampu memenuhi kewajiban yang ditanggungnya yaitu dengan mengerahkan aktifitas karyawannya untuk dapat menambah jumlah anggota khususnya funding, dengan demikian tingkat perputaran keuangan KJKS Mass Group akan teratasi dengan sendirinya.

\section{Rasio Solvabilitas}

a. Rasio total hutang terhadap total aktiva KJKS selama tahun 2012 dan 2013 menghasilkan angka rasio yang buruk, yaitu $91,46 \%$ dan $91,58 \%$ di mana angka-angka tersebut di bawah dari standar yang ditentukan. Hal tersebut disebabkan total kekayaan Kjkstidak dapat memberikan sebuah kontribusi cukup memadai terhadap hutang yang ditanggungnya. Dari analisis tersebut menunjukkan tingkat kinerja keuangan KJKS masih kurang baik/solvabel dalam memenuhi semua kewajiban yang harus dipenuhi.

b. Rasio hutang jangka panjang terhadap modal sendiri

Tahun 2012 dan 2013, KJKS Mass Group menghasilkan angka rasio $255,13 \%$ dan $190,57 \%$ sehingga dikatagorikan buruk. Hal itu menjelaskan besar modal sendiri KJKS Mass Group belum cukup solvabel dalam memenuhi semua kewajiban jangka panjang.

\section{Rasio Rentabilitas}

a. Return of Investment

KJKS Mass Group selama tahun 2012 dan 2013 pada analisis ROI menghasilkan angka rasio $1,81 \%$ dengan kriteria kurang baik serta angka rasio 1,88\% dengan kriteria kurang baik. Dapat diartikan KJKS Mass Group belum mampu menggunakan aktiva yang dimiliki secara produktif (belum dapat menghasilkan SHU maksimal) dengan kata lain, KJKS Mass Group menujukkan hasil rentabilitas ekonomi yang kurang rentabel. 


\section{b. Return on Equity}

KJKS Mass Group di tahun 2012 dan 2013 menghasilkan angka rasio $25,96 \%$ dengan kriteria sangat baik; dan angka rasio $27,79 \%$ dengan kriteria sangat baik. Hasil analisis menunjukkan modal KJKS Mass Group sangat rentabel dalam menghasilkan SHU secara maksimal.

\section{KESIMPULAN}

Dari analisis di atas, dapat diambil kesimpulan, Pertama, Analisis likuiditas pada KJKS Mass Group dilihat berdasarkan angka rasio memperoleh hasil baik atau likuid pada analisis Current Ratio yaitu dengan angka sebesar 122,01\% pada tahun 2012 dan $153,11 \%$ pada tahun 2013, sedangkan pada analisis Cash Ratio menunjukkan hasil yang tidak baik karena masih jauh dari ketentuan yang ada. Kedua, Analisis Solvabilitas pada KJKS Mass Group menunjukkan hasil yang tidak baik atau tidak solvabel dalam memenuhi kewajibannya (jangka panjang maupun jangka pendek). Hal ini dilihat dari hasil analisis yang menunjukkan angka yang tidak sesuai standar yang telah ditetapkan. Ketiga, Analisis Rentabilitas menunjukkan bahwa KJKS Mass Group tidak rentabel dalam menghasilkan sisa hasil usaha (SHU) yang maksimal. Hal ini dilihat dari angkaangka rasio yang dihasilkan tidak sesuai dengan standar yang telah ditetapkan.

\section{DAFTAR PUSTAKA}

Dahlan, Abdul Aziz. et.al. (1999). Ensiklopedi Hukum Islam. Cetakan II. Jakarta: PT Ichtiar Baru van Hoeve.

Arikunto, Suharsimi. (1998). Prosedur Penelitian Suatu Pendekatan Praktik. Jakarta: Rinika Cipta.
(2006). Prosedur Penelitian Suatu Pendekatan Praktik. Jakarta: Rinika Cipta.

Baridwan. (2004). Intermediete Accounting. Yogyakarta: BPFE.

Hasibuan. (2001). Akuntansi Manajemen. Yogyakarta : Balai Pustaka.

Ikatan Akuntansi Indonesia. (2002). Standar Akuntansi Keuangan. Jakarta: Salemba Empat.

Keputusan Menteri Koperasi dan UKM nomor 91/Kep/M.KUKM/IX/2004 tentang Petunjuk Pelaksanaan Kegiatan Usaha Koperasi Jasa Keuangan Syariah.

Keputusan Menteri Koperasi dan UKM nomor 96/Kep/ M.KUKM/IX/2004 tentang Pedoman Standar Operasional Manajemen Koperasi Simpan Pinjam dan Unit Simpan Pinjam Koperasi.

Mangkunegara, Anwar Prabu. (2000). Manajemen Sumber Daya Manusia Perusahaan. Bandung: PT. Remaja Rosdakarya.

Mink. (1993). Karakteristik Kinerja Individu. Jakarta: Balai Pustaka.

Muhammad. (2005). Manajemen Pembiayaan Bank Syariah. Yogyakarta: UUP AMP YKPN.

Munawir. (2002). Analisa Laporan Keuangan. Yogyakarta: Liberty.

Nainggolan. (2004). Analisa Laporan Keuangan. Yogyakarta: BPPE.

PINBUK. Tanpa Tahun. Peraturan Dasar dan Contoh AD ART MT. Jakarta: Wasantara Net. Id.

Sulistiyani. (2003). Akuntansi Manajemen. Yogyakarta: Liberty.

Tho'in, M. (2011). Pengaruh Faktor-faktor Kualitas Jasa terhadap Kepuasan Nasabah di Baitul Mal Wat Tamwil (BMT) Tekun Karanggede Boyolali. MUQTASID Jurnal Ekonomi dan Perbankan Syariah, 2(1), 73-89.

Wardani, H. K., \& Tho'in, M. (2013). Pengelolaan Baitul Maal Dalam Meningkatkan Kesejahteraan Negara. Jurnal Akuntansi dan Pajak, 14(01). 